Article

\title{
Possible Role of Envelope Components in the Extreme Copper Resistance of the Biomining Acidithiobacillus ferrooxidans
}

\author{
Nia Oetiker ${ }^{1}$, Rodrigo Norambuena ${ }^{1}$, Cristóbal Martínez-Bussenius ${ }^{1}$, Claudio A. Navarro ${ }^{1}$, \\ Fernando Amaya ${ }^{2}$, Sergio A. Álvarez ${ }^{2}$, Alberto Paradela ${ }^{3}$ and Carlos A. Jerez ${ }^{1, *}$ \\ 1 Laboratory of Molecular Microbiology and Biotechnology, Department of Biology, Faculty of Sciences, \\ University of Chile, Santiago 7800003, Chile; nia.oetiker.mancilla@gmail.com (N.O.); \\ rodrigoanv93@gmail.com (R.N.); cm.bussenius@gmail.com (C.M.-B.); clnavarrol@gmail.com (C.A.N.) \\ 2 Department of Biochemistry and Molecular Biology, Faculty of Chemical and Pharmaceutical Sciences, \\ University of Chile, Santiago 7800003, Chile; fernando.amaya@ug.uchile.cl (F.A.); \\ salvarez@uchile.com (S.A.Á.) \\ 3 Proteomics Laboratory, National Biotechnology Center, CSIC, 28049 Madrid, Spain; \\ alberto.paradela@cnb.csic.es \\ * Correspondence: cjerez@uchile.cl; Tel.: +56-2-29787376
}

Received: 30 May 2018; Accepted: 3 July 2018; Published: 10 July 2018

\begin{abstract}
Acidithiobacillus ferrooxidans resists extremely high concentrations of copper. Strain ATCC 53993 is much more resistant to the metal compared with strain ATCC 23270, possibly due to the presence of a genomic island in the former one. The global response of strain ATCC 53993 to copper was analyzed using iTRAQ (isobaric tag for relative and absolute quantitation) quantitative proteomics. Sixty-seven proteins changed their levels of synthesis in the presence of the metal. On addition of CusCBA efflux system proteins, increased levels of other envelope proteins, such as a putative periplasmic glucan biosynthesis protein (MdoG) involved in the osmoregulated synthesis of glucans and a putative antigen $\mathrm{O}$ polymerase (Wzy), were seen in the presence of copper. The expression of $A$. ferrooxidans $m d o G$ or wzy genes in a copper sensitive Escherichia coli conferred it a higher metal resistance, suggesting the possible role of these components in copper resistance of $A$. ferrooxidans. Transcriptional levels of genes $w z y, r f a E$ and $w z z$ also increased in strain ATCC 23270 grown in the presence of copper, but not in strain ATCC 53993. Additionally, in the absence of this metal, lipopolysaccharide (LPS) amounts were 3-fold higher in A. ferrooxidans ATCC 53993 compared with strain 23270. Nevertheless, both strains grown in the presence of copper contained similar LPS quantities, suggesting that strain 23270 synthesizes higher amounts of LPS to resist the metal. On the other hand, several porins diminished their levels in the presence of copper. The data presented here point to an essential role for several envelope components in the extreme copper resistance by this industrially important acidophilic bacterium.
\end{abstract}

Keywords: Acidithiobacillus ferrooxidans; copper resistance; biomining; envelope components; proteomics; lipopolysaccharide

\section{Introduction}

Acidithiobacillus ferrooxidans is a gram-negative, acidophilic, chemolithoautotrophic bacterium able to use ferrous iron, reduced species of sulfur or metal sulfides as energy sources [1-5]. These bacteria are able to grow at high concentrations of several metals. This is an important property since they are used in biomining processes where copper concentrations are in the range of 15 to $100 \mathrm{mM}$ [6-8]. Furthermore, these microorganisms can be used to exploit these natural resources sustainably [9]. 
Current knowledge indicates that $A$. ferrooxidans uses key elements involved in copper resistance in all bacteria [10-12], but in addition, it may have a broader repertoire of these known copper resistance determinants $[13,14]$.

In the biomining environment, copper and other toxic metals are present in concentrations that are one to two orders of magnitude greater than those tolerated by neutrophils [6,15-18]. Most likely, the microorganisms forming part of the biomining consortium have developed additional strategies to resist the harsh conditions in which they live, and their study is therefore of great interest $[19,20]$.

A. ferrooxidans ATCC 53993 is much more resistant to copper and other metals than A. ferrooxidans ATCC 23270. Both strains have the same copper resistance determinants but strain ATCC 53993 contains a genomic island (GI) having 160 extra genes, some of which code for additional copies of proteins involved in copper tolerance [13,14].

The response to copper of both A. ferrooxidans ATCC 53993 and ATCC 23270 was previously compared at $40 \mathrm{mM} \mathrm{CuSO}_{4}[14,21,22]$. These preliminary studies were done by using ICPL (isotope-coded protein labeling) quantitative proteomics [22] and showed that strain ATCC 23270 synthesized much more oxidative-stress-related proteins than strain 53993 in response to copper, clearly indicating that the former strain is much more sensitive to the metal [22]. A high overexpression of RND (Resistance-Nodulation-Division) efflux systems and copper periplasmic chaperones CusF were seen in both strains subjected to copper. However, in strain ATCC 53993 both of its additional genes present in its genomic island were also overexpressed. This behavior suggested a possible explanation for the much higher copper resistance of strain ATCC 53993. In addition, changes in the levels of the respiratory system copper-binding proteins AcoP, Rus and several other proteins with predicted functions suggested that numerous metabolic changes are involved in controlling the effects of the toxic metal in strain ATCC 53993 [22].

To understand in more detail the reason by which A. ferrooxidans ATCC 53993 stands higher copper concentrations compared with strain 23270, iTRAQ (isobaric tag for relative and absolute quantitation) proteomics, transcriptional expression of genes of interest and functional assays were used in the current report. Increased levels of novel possible copper resistance determinants present in the envelope of A. ferrooxidans ATCC 53993 such as outer membrane proteins, the periplasmic glucans synthesizing protein MdoG and proteins involved in lipopolysaccharide (LPS) synthesis, amongst others, were found in cells grown in the presence of copper. In addition, determination of the relative amounts of LPS present in the cells of each A. ferrooxidans strain also supports the idea that these polymers may also have an important role in copper resistance in these biomining bacteria.

\section{Materials and Methods}

\subsection{Bacterial Strains and Growth Conditions}

A. ferrooxidans strains ATCC 53993 and ATCC 23270 were grown at $30{ }^{\circ} \mathrm{C}$ in liquid $9 \mathrm{~K}$ medium containing ferrous sulfate ( $33.33 \mathrm{~g} / \mathrm{L})$ with an initial $\mathrm{pH}$ of 1.45 as previously described [23] and in absence or presence of $\mathrm{CuSO}_{4}$. Copper concentrations between 40 and $300 \mathrm{mM}$ were used depending on the experiment. In some experiments, concentrations of 100 or $200 \mathrm{mM}$ were used for A. ferooxidans ATCC 53993 without prior adaptation since under these two conditions, similar cells numbers to control cells (in absence of copper) were obtained at their respective late exponential growth phases. At $300 \mathrm{mM}$ copper strain ATCC 53993 required previous adaptation. On the other hand, to compare the effect of the metal at the same copper concentration in both strains, it was necessary to adapt strain ATCC 23270 to grow at $100 \mathrm{mM}$ copper. For LPS determinations, strain ATCC 23270 was adapted to grow at $100 \mathrm{mM}$ and strain ATCC 53993 to $200 \mathrm{mM}$ copper. These adaptations were done starting with cells grown at $50 \mathrm{mM}$ copper by increasing $5 \mathrm{mM}$ copper in each successive culture until the desired concentrations were reached. After cells attained late exponential growth phases they were collected and triplicate separate cultures were employed for all experiments. Bacterial growth was determined 
by measuring the increase in cell numbers by using an Olympus BX50 optical microscope (Olympus, Tokyo, Japan) and a Petroff-Hausser counting chamber (Horsham, PA, USA).

\subsection{Preparation of Total Protein Extracts for iTRAQ Analysis}

A. ferrooxidans ATCC 53993 was grown with ferrous iron as oxidizable substrate until late exponential phase in absence or presence of 100 or $200 \mathrm{mM} \mathrm{CuSO}_{4}$. Cells were harvested by centrifugation $\left(4000 \times \mathrm{g}\right.$ for $15 \mathrm{~min}$ ) and washed three times by centrifugation at $4{ }^{\circ} \mathrm{C}$ with dilute sulfuric acid ( $\mathrm{pH}$ 1.5). This was followed by three washes with $50 \mathrm{mM}$ sodium citrate, $\mathrm{pH} 7.0$ by centrifugation at $4{ }^{\circ} \mathrm{C}$ to remove any minor ferrous iron remaining and at the same time, to neutralize the $\mathrm{pH}$ before cell rupture by sonic oscillation. Cells were then resuspended in sonication buffer $(50 \mathrm{mM}$ Tris- $\mathrm{HCl} \mathrm{pH}$ 8.0, 1 mM ethylenediaminetetra-acetic acid (EDTA) containing phenylmethylsulfonyl fluoride (PMSF) as protease inhibitor $(100 \mu \mathrm{g} / \mathrm{mL})$ and were disrupted by sonic oscillation during $25 \mathrm{~min}$ on ice by using successive $5 \mathrm{~s}$ pulses and pauses. Finally, the lysate was centrifuged at 10,000 $\times$ $g$ for $10 \mathrm{~min}$ to remove unbroken cells and cell debris and the total protein amount in the cell-free extract was determined [21].

\subsection{Protein Digestion and Tagging with iTRAQ-8-Plex ${ }^{\circledR}$ Reagent}

Total protein concentration was determined using microBCA protein assay kit (Pierce, Appleton, WI, USA). For digestion, $50 \mu \mathrm{g}$ of protein from each condition was precipitated by the methanol/chloroform method. Protein pellets were resuspended and denatured in $20 \mu \mathrm{L}$ of $7 \mathrm{M}$ urea, $2 \mathrm{M}$ thiourea, $100 \mathrm{mM}$ TEAB (triethylammonium bicarbonate), reduced with $2 \mu \mathrm{L}$ of $50 \mathrm{mM}$ Tris 2-carboxyethyl phosphine (TCEP) (AB SCIEX, Foster City, CA, USA), pH 8.0, at $37^{\circ} \mathrm{C}$ for $60 \mathrm{~min}$ and followed by $2 \mu \mathrm{L}$ of $200 \mathrm{mM}$ cysteine-blocking reagent methyl methanethiosulfonate (MMTS) (Pierce) for $10 \mathrm{~min}$ at room temperature. Samples were diluted up to $120 \mu \mathrm{L}$ with $50 \mathrm{mM}$ TEAB to reduce the concentration of urea. Two $\mu$ g of sequence grade-modified trypsin (Sigma-Aldrich, St. Louis, MO, USA) was added to each sample (ratio 1:25 enzyme:sample, which were then incubated at $37^{\circ} \mathrm{C}$ overnight on a shaker. After digestion, samples were dried in a SpeedVac (Thermo Scientific, Waltham, MA, USA).

Each sample was reconstituted with $180 \mu \mathrm{L}$ of 70\% ethanol/50 mM TEAB, the different versions of the iTRAQ reagent 8-plex (AB SCIEX) were added in additional $20 \mu \mathrm{L}$ and the mixture was incubated for $2 \mathrm{~h}$ at room temperature, according to the following labeling scheme: iTRAQ 113/117 reagent: control 1 and control 2 A. ferrooxidans; iTRAQ 115/119 reagent: A. ferrooxidans grown in $100 \mathrm{mM} \mathrm{CuSO}_{4}$, 1 and grown in $100 \mathrm{mM} \mathrm{CuSO}_{4}$, 2; iTRAQ 116/121 reagent: $A$. ferrooxidans grown in $200 \mathrm{mM} \mathrm{CuSO}_{4}$, 1 and grown in $200 \mathrm{mM} \mathrm{CuSO}_{4}, 2$. Two biological replicas were used in each case. After labeling, samples were combined and the reaction was stopped by evaporation in the SpeedVac.

\subsection{Liquid Chromatography and Mass Spectrometry Analysis}

A 2- $\mu$ g aliquot of the combined sample was subjected to 2D-nano Liquid Chromatography-Electrospray Ionization Tandem Mass Spectrometry LC ESI-MSMS analysis using a nano liquid chromatography system nanoLC Ultra 1D plus, (Eksigent Technologies, AB SCIEX) coupled to a Quadrupole time of flight (QTOF) type, high speed Triple TOF 5600 mass spectrometer (AB SCIEX) equipped with a nanospray source. Injection volume was $5 \mu \mathrm{L}$ and three independent technical replicas were analyzed. The analytical column used was a silica-based reversed phase Acquity UPLC Peptide BEH C18 column $75 \mu \mathrm{m} \times 15 \mathrm{~cm}, 1.7 \mu \mathrm{m}$ particle size and $130 \AA$ A pore size (Waters, Dublin, Ireland). The trap column was a C18 Acclaim PepMap (Eksigent Technologies, AB SCIEX), $100 \mu \mathrm{m} \times 2 \mathrm{~cm}, 5 \mu \mathrm{m}$ particle diameter, $100 \AA$ pore size, switched on-line with the analytical column. The loading pump delivered a solution of $0.1 \%$ formic acid in water at $2 \mu \mathrm{L} / \mathrm{min}$. The nano-pump provided a flow-rate of $300 \mathrm{~nL} / \mathrm{min}$ and was operated under gradient elution conditions, using $0.1 \%$ formic acid in water as mobile phase $\mathrm{A}$, and $0.1 \%$ formic acid in acetonitrile as mobile phase B. Gradient elution was performed according to the following scheme: Isocratic 
conditions of $96 \%$ A: 4\% B for $5 \mathrm{~min}$, a linear increase to $40 \%$ B in $205 \mathrm{~min}$, then a linear increase to $90 \%$ $\mathrm{B}$ for 15 additional minutes, isocratic conditions of $90 \% \mathrm{~B}$ for $10 \mathrm{~min}$ and return to initial conditions in $2 \mathrm{~min}$. Total gradient length was $250 \mathrm{~min}$.

Data acquisition was performed with a TripleTOF 5600 System (AB SCIEX). Ionization occurred under the following conditions: Ionspray voltage floating (ISVF) $2800 \mathrm{~V}$, curtain gas (CUR) 20, interface heater temperature (IHT) 150, ion source gas 1 (GS1) 20, declustering potential (DP) 85 V. All data was acquired using information-dependent acquisition (IDA) mode with Analyst TF 1.5 software (AB SCIEX). For IDA parameters, $0.25 \mathrm{~s}$ MS survey scan in the mass range of 350-1250 Da were followed by $25 \mathrm{MS} / \mathrm{MS}$ scans of $150 \mathrm{~ms}$ in the mass range of 100-1500 (total cycle time: $4 \mathrm{~s}$ ). Switching criteria were set to ions greater than mass to charge ratio $(\mathrm{m} / \mathrm{z}) 350$ and smaller than $m / z 1250$ with charge state of 2-5 and an abundance threshold of more than 90 counts (cps). Former target ions were excluded for $20 \mathrm{~s}$. IDA rolling collision energy (CE) parameters script was used for automatically controlling the $\mathrm{CE}$.

\subsection{Data Analysis and Statistics}

MS/MS spectra were exported to Mascot generic format (mgf) using Peak View v1.2.0.3 and searched using OMSSA 2.1.9, X!TANDEM 2013.02.01.1, Myrimatch 2.2.140 and MS-GF+ (Beta v10072) [24] against a composite target/decoy database built from the $2748 \mathrm{~A}$. ferrooxidans sequences at UniprotKB (June 2014). Search engines were configured to match potential peptide candidates with mass error tolerance of $25 \mathrm{ppm}$ and fragment ion tolerance of $0.02 \mathrm{Da}$, allowing for up to two missed tryptic cleavage sites and a maximum isotope error (13C) of 1, considering fixed MMTS modification of cysteine and variable oxidation of methionine, pyroglutamic acid from glutamine or glutamic acid at the peptide $\mathrm{N}$-terminus, and modification of lysine and peptide $\mathrm{N}$-terminus with iTRAQ 8-plex reagents. Score distribution models were used to compute peptide-spectrum match $p$-values [24], and spectra recovered by a false discovery rate (FDR) $\leq 0.01$ (peptide-level) filter were selected for quantitative analysis. Approximately $5 \%$ of the signals with the lowest quality were removed prior to further analysis. Differential regulation was measured using linear models [25], and statistical significance was measured using $q$-values (FDR). All analyses were conducted using software from Proteobotics (Madrid, Spain) [24].

\subsection{Extraction of Total RNA from Acidithiobacillus ferrooxidans and Complementary DNA Synthesis}

To determine the effect of copper on the expression of some genes of interest, A. ferrooxidans ATCC 23270 and ATCC 53993 cells were grown in absence or presence of $\mathrm{CuSO}_{4}$ until cells reached late exponential phase of growth. At this time, total RNA was extracted from each culture condition by lysing the cells as previously reported [26], except that TRIzol (Invitrogen, Carlsbad, CA, USA) was used for the extraction $[27,28]$. Between three to five biological replicas were used for each experimental condition. Any remaining DNA was eliminated from RNA preparations by addition of 4 U of TURBO DNA-free DNase (Ambion, Thermo Scientific) following manufacturer's instructions. For complementary DNA (cDNA) synthesis, $0.8 \mu \mathrm{g}$ of total RNA was reverse transcribed for $1 \mathrm{~h}$ at $42{ }^{\circ} \mathrm{C}$ using ImProm-II (Promega, Madison, WI, USA) reverse transcription system, $0.5 \mu \mathrm{g}$ of random hexamers (Promega) and $3 \mathrm{mM} \mathrm{MgCl} 2$ [28].

\subsection{Primer Design, Real-Time PCR and Cloning of A. ferrooxidans Genes}

Primers for quantitative real time PCR (qRT-PCR) were designed using the Primer3 software [29]. After separating PCR products by electrophoresis in a $1 \%$ agarose gel $(0.5 \times$ Tris-acetate-EDTA $\mathrm{pH} 8.0$ buffer), no cross-amplification or non-specific bands were detected. Copper-resistance related gene expression was analyzed by qRT-PCR with either the Corbett Rotor Gene 6000 system as described previously [21] or with the 96-well PikoReal Real-Time PCR System and Thermo Scientific PikoReal Software 2.2. Efficiency of each primer pair was calculated from the average slope of a linear regression curve, which resulted from qPCRs using a 10-fold dilution series (10 pg-10 ng) of A. ferrooxidans DNA as template. Efficiencies between 90 and $110 \%$ were used. Quantification cycle $(\mathrm{Cq})$ values were 
automatically determined by Real-Time Rotor-gene 6000 PCR software (Corbett Life Sciences, Thermo Scientific/Qiagen, Hilden, Germany) or by Thermo Scientific PikoReal Software 2.2.

For transcriptional analysis of the different genes studied, a relative quantification method was used which is based in the ratio between the transcripts of a study sample (in presence of copper) versus a control sample (no copper) [30]. 16S $\mathrm{rRNA}_{A f}$ was selected as a reference gene since its expression was found to be the most stable under our experimental conditions. To carry out the real-time PCR, $0.5 \mu \mathrm{L}$ of $1: 20$ diluted cDNA or $0.5 \mu \mathrm{L}$ of $1: 200$ diluted $16 \mathrm{~S}_{\mathrm{rRNA}}, 0.2 \mu \mathrm{L}$ of each primer $(10 \mu \mathrm{M})$ and $5.0 \mu \mathrm{L}$ of master mix Rotor-Gene SYBR Green PCR (Qiagen) in a final volume of $10 \mu \mathrm{L}$, completed with RNA-free water were used. The program used was $10 \mathrm{~min}$ at $95^{\circ} \mathrm{C}$ followed by 40 cycles of $5 \mathrm{~s}$ at $95^{\circ} \mathrm{C}$ and $20 \mathrm{~s}$ at $60^{\circ} \mathrm{C}$.

\subsection{Cloning A. ferrooxidans Genes in an Expression Vector}

The functionality of different putative copper resistance genes from A. ferrooxidans was tested by using heterologous expression in Escherichia coli. A copper-sensitive E. coli $\mathrm{K}-12$ $(\triangle c o p A / \triangle c u s C F B A / \triangle c u e O)$ mutant was transformed with vector $\mathrm{p}$ Trc-His2A (Invitrogen) containing the genes of interest under the control of a promoter induced by IPTG, and minimal inhibitory concentration (MIC) values of these transformants were determined as described before [14,28].

\subsection{Lipopolysaccharide Extraction}

A. ferrooxidans cells grown in absence or presence of $\mathrm{CuSO}_{4}$ were harvested by centrifugation $\left(10,000 \times g\right.$ for $5 \mathrm{~min}$, at $\left.4{ }^{\circ} \mathrm{C}\right)$. Cell pellets were washed twice with sulfuric acid solution ( $\left.\mathrm{pH} 1.5\right)$ and twice with $10 \mathrm{mM}$ sodium citrate $(\mathrm{pH} 7)$ by resuspension followed by centrifugation $(9200 \times g$ for 1 $\mathrm{min})$. Cells were then resuspended in sulfuric acid solution. To normalize the number of cells, optical density of cell suspensions was measured at $600 \mathrm{~nm}$, adjusting them to an optical density of $2\left(\mathrm{OD}_{600 \mathrm{~nm}}\right.$ $=2$ ) in $1 \mathrm{~mL}$ of sulfuric acid solution. Cell suspensions were then centrifuged at $10,000 \times g$ for $5 \mathrm{~min}$. A partially modified Hitchcock \& Brown method for LPS extraction was used [31]. The cell pellet was resuspended in $90 \mu \mathrm{L}$ of lysis buffer solution (2\% Sodium dodecyl sulfate (SDS); $4 \%$ 2-ME; $0.5 \mathrm{M}$ Tris- $\mathrm{HCl}, \mathrm{pH}$ 9.0). The suspension was heated for $30 \mathrm{~min}$ at $100^{\circ} \mathrm{C}$. Lysed cells were then digested with $100 \mu \mathrm{g} / \mathrm{mL}$ of DNase I (Ambion) for $90 \mathrm{~min}$ at $37^{\circ} \mathrm{C}$. Samples were thereafter treated with $1 \mathrm{mg} / \mathrm{mL}$ of Proteinase K (Sigma-Aldrich) for $90 \mathrm{~min}$ at $60^{\circ} \mathrm{C}$. Finally, samples were dialyzed for $30 \mathrm{~min}$ against nano-pure water using a nitrocellulose membrane, $0.025 \mu \mathrm{m}$ pore size. Dialyzed samples were finally stored at $4{ }^{\circ} \mathrm{C}$ for further analysis.

\subsection{Lipopolysaccharide Quantification}

Extracted LPS was quantified by purpald assay [32]. Unsubstituted terminal vicinal glycol (UTVG) groups of the sugar residues such as Kdo and heptose in LPS can be subjected to periodate oxidation, yielding quantitative formaldehyde measurable by the purpald reagent. This assay provides the molarity of the UTVG present in LPS. LPS molarity can be found by dividing the molarity of the UTVG by the theoretical number of UTVG per LPS molecule. The numbers of UTVG present in LPS of A. ferrooxidans is unknown. Therefore, LPS concentration was expressed in relation to the molarity of UTVG present in each sample. The experimental procedure was carried out as previously described [33].

\section{Results and Discussion}

\subsection{Proteomic Analysis of the Copper Response of A. ferrooxidans ATCC 53993}

Proteins of cells grown in ferrous iron and in presence of 100 or $200 \mathrm{mM} \mathrm{CuSO}_{4}$ were analyzed by quantitative iTRAQ proteomics. In cells subjected to $100 \mathrm{mM}$ of copper 1656 proteins were identified, of which 28 changed their levels compared to control cells grown in absence of copper. Of these proteins, 11 had higher levels and 17 showed lower amounts (Table S1). On the other hand, in cells 
grown in $200 \mathrm{mM}$ copper 1567 proteins were identified and 59 of these showed changes in their levels compared to the control. Seventeen showed higher levels than the control and 42 lower amounts (Table S1). This corresponds to about 2-fold more proteins changing at $200 \mathrm{mM}$ than at $100 \mathrm{mM}$ copper (Table S1). Most of the proteins changing at $100 \mathrm{mM}$ copper were also seen to vary at $200 \mathrm{mM}$ of the metal (Tables S2 and S3). The functional categories of all proteins changing in A. ferrooxidans 53993 are shown in Table S1 and Figure S1 and the data obtained is seen in Tables S2 and S3. Although at $200 \mathrm{mM}$ copper ATCC 53993 cells grew reaching similar numbers to the control, they were apparently more affected than cells subjected to $100 \mathrm{mM}$ copper since a greater number of proteins related to metabolism and protein biosynthesis decreased their levels whereas others related to energy production and copper resistance increased their amounts. Nevertheless, at $200 \mathrm{mM}$ copper cells are still actively expressing the proteins related to the RND efflux systems (Table 1), as seen before at $40 \mathrm{mM}$ copper sulfate [22]. In addition, an interesting group of proteins that also form part of the cell envelope changed their synthesis levels in presence of the metal (Table 1). Most of these proteins may be new possible copper resistance determinants present in A. ferrooxidans ATCC 53993.

Table 1. Levels of some selected known and new possible copper resistance determinants in $A$. ferrooxidans ATCC 53993 grown in the presence of $200 \mathrm{mM} \mathrm{CuSO}_{4}$.

\begin{tabular}{|c|c|c|c|c|c|c|}
\hline Function/Similarity & ORF & Name & $\begin{array}{l}\text { q Value } \\
\text { (FDR) }\end{array}$ & $\begin{array}{c}\text { Coverage } \\
(\%)\end{array}$ & $\begin{array}{l}\text { Peptide } \\
\text { Number }\end{array}$ & $\begin{array}{c}\log _{2} \text { Fold Change } \\
(\mathrm{Cu} 200 / 0 \mathrm{mM})\end{array}$ \\
\hline $\begin{array}{l}\text { Outer membrane efflux } \\
\text { protein }\end{array}$ & Lferr_1619 & CusC1 & 0.001 & 45 & 9 & 1.258 \\
\hline $\begin{array}{l}\text { Efflux transporter, RND } \\
\text { family, MFP subunit }\end{array}$ & Lferr_1618 & CusB1 & 0.001 & 63.3 & 15 & 0.859 \\
\hline Uncharacterized protein & Lferr_2057 & CusF2 & 0.001 & 60 & 3 & 1.92 \\
\hline Uncharacterized protein & Lferr_0174 & CusF3 & 0.001 & 60 & 3 & 1.63 \\
\hline $\begin{array}{l}\text { Heavy metal efflux pump, } \\
\text { CzcA family }\end{array}$ & Lferr_0172 & CusA3 & 0.001 & 39.1 & 10 & 1.019 \\
\hline $\begin{array}{l}\text { Outer membrane efflux } \\
\text { protein }\end{array}$ & Lferr_2062 & CusC2 & 0 & 45 & 12 & 1.084 \\
\hline $\begin{array}{l}\text { Heavy metal efflux pump, } \\
\text { CzcA }\end{array}$ & Lferr_1617 & CusA1 & 0.002 & 35 & 9 & 0.855 \\
\hline $\begin{array}{l}\text { Efflux transporter, RND } \\
\text { family, MFP subunit }\end{array}$ & Lferr_2061 & CusB2 & 0.003 & 68.3 & 6 & 0.968 \\
\hline $\begin{array}{l}\text { Heavy metal efflux pump, } \\
\text { CzcA family }\end{array}$ & Lferr_2060 & CusA2 & 0.003 & 38.3 & 9 & 0.846 \\
\hline $\begin{array}{c}\text { Periplasmic glucan } \\
\text { biosynthesis protein } \\
\text { MdoG }\end{array}$ & Lferr_1075 & MdoG & 0.009 & 48.1 & 15 & 0.415 \\
\hline $\begin{array}{c}\text { Carbohydrate-selective } \\
\text { porin OprB }\end{array}$ & Lferr_1898 & OprB & 0.005 & 36.46 & 10 & -0.635 \\
\hline O-antigen polymerase & Lferr_0408 & Wzy & 0.026 & 3.19 & 1 & 1.795 \\
\hline
\end{tabular}

\subsection{Overexpression of Resistance-Nodulation-Division Efflux Transporters and Possible Generation of Excess Acidity}

Transcriptional levels of some genes coding for possible components of the RND family of efflux transporters [10] are shown in Figure 1. These correspond to most of the genes coding for Cus system components in both A. ferrooxidans ATCC 53993 [20,22] and ATCC 23270 [28]. All these genes showed increased transcriptional levels in cells grown at the indicated copper concentrations. These Cus transporter systems are widely present in bacteria to remove copper from the cell [10]. A. ferrooxidans lives at an acid external $\mathrm{pH}(1-3)$ and its cytoplasmic $\mathrm{pH}$ is up to 5 units higher than external $\mathrm{pH}$. This generates an elevated $\mathrm{pH}$ gradient across the cytoplasmic membrane that contributes to the proton motive force $(\mathrm{PMF})$ comprising membrane potential $(\Delta \Psi)$ and transmembrane $\mathrm{pH}$ difference 
$(\Delta \mathrm{pH})[22,34]$. RND type transporters are antiporters taking advantage of the proton gradient to efflux copper with the concomitant protons entrance to the cytoplasm. Due to its economy from the energetic point of view, these systems would be used preferentially by acidophilic microorganisms to remove intracellular copper.

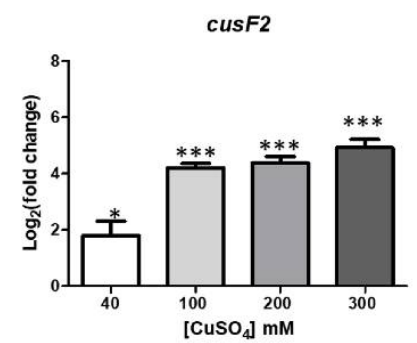

(A)

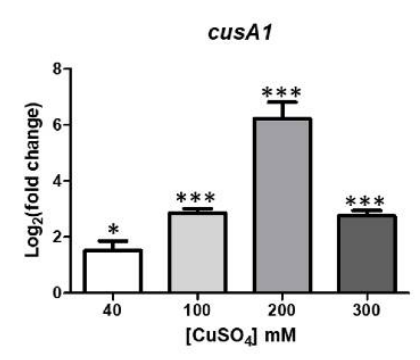

(D)

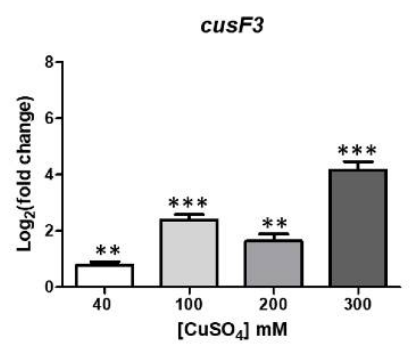

(B)

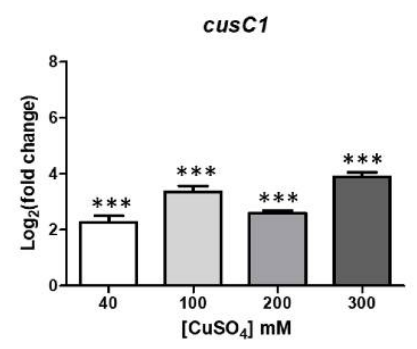

(E)

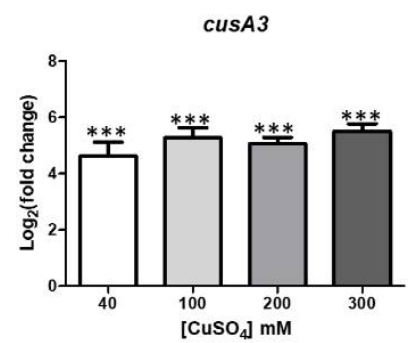

(C)

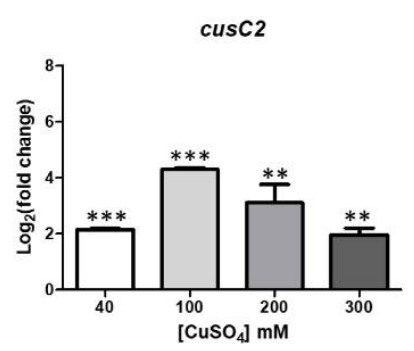

(F)

Figure 1. Transcriptional levels of several genes coding for Cus system components in Acidithiobacillus ferrooxidans ATCC 53993. The transcriptional levels of genes (A) cusF2; (B) cusF3; (C) cusA3; (D) cusA1; (E) $c u s C 1$ and (F) cusC2 were determined at the indicated copper concentrations as described in Material and Methods section. Error bars indicate the standard deviations based on three different experimental values. Application of $t$-Student test were: ${ }^{* * *} p \leq 0.001^{* *} p \leq 0.01$ and ${ }^{*} p \leq 0.05$.

A possible cytoplasmic acidification would be expected if these efflux pumps were excessively used by A. ferrooxidans in presence of high metal concentrations. Conversely, as previously pointed out [22], this acidification could be diminished by the energetic metabolism of the bacterium, since oxidation of Fe(II) by molecular oxygen as the final electron acceptor consumes protons [35]. Still, RND systems may introduce an excess of protons from the acid culture medium to the cell during copper detoxification. This idea has not been demonstrated in A. ferrooxidans. However, a possible increase in the extracellular $\mathrm{pH}$ of the growth medium could be expected during growth in the presence of copper. Figure 2A shows growth curves of A. ferrooxidans ATCC 53993 and how cell growth was affected at the indicated copper concentrations. Initially, there was a strong partial inhibition of growth only at $300 \mathrm{mM}$ copper.

Figure 2B clearly shows an increase in external $\mathrm{pH}$ of the growth medium (reaching around $0.6 \mathrm{pH}$ units at $300 \mathrm{mM}$ copper). On the contrary, $\mathrm{pH}$ values of control media containing different copper concentrations and no cells inoculated showed only very minor $\mathrm{pH}$ variations. Clearly, whether this interesting preliminary observation is due to intracellular acidification remains to be demonstrated. 

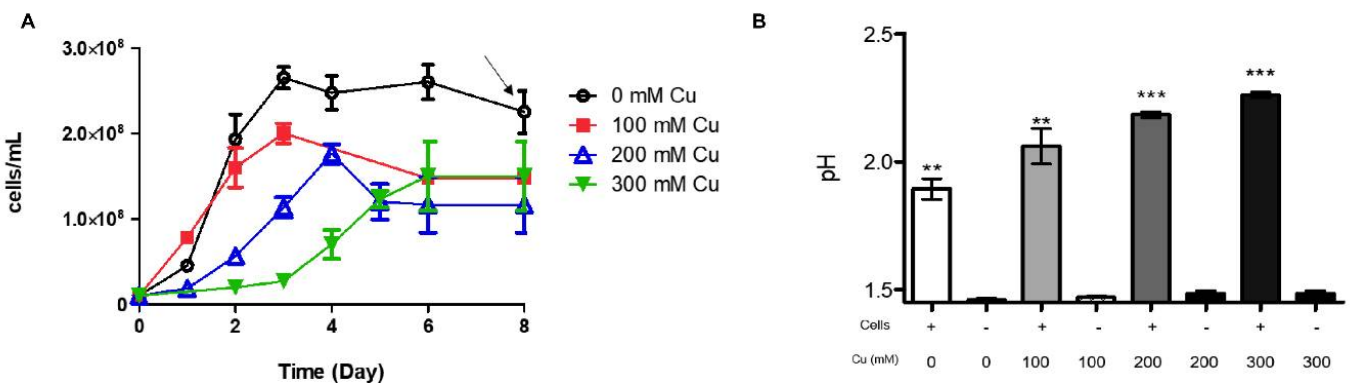

Figure 2. Growth medium $\mathrm{pH}$ changes of A. ferrooxidans ATCC 53993 grown in absence or presence of copper. (A) Cells were grown in ferrous iron medium at the indicated copper concentrations. Once cells reached stationary phase of growth (indicated by the arrow), aliquots of the cultures were taken and centrifuged to remove cells; (B) $\mathrm{pH}$ values of the media supernatants were determined and compared with $\mathrm{pH}$ changes of the medium containing the same copper concentrations but in absence of inoculated cells. Error bars indicate standard deviations based on three different experimental values. Application of $t$-Student test were: ${ }^{* *} p \leq 0.001{ }^{* *} p \leq 0.01$ and ${ }^{*} p \leq 0.05$.

\subsection{Changes of Several Additional Envelope Components Occur in Presence of High Copper Concentrations}

Another protein with increased levels in cells grown in presence of copper was a putative periplasmic glucan biosynthesis protein MdoG coded by Lferr_1075 (Table 1). This protein is involved in the synthesis of ramifications present in the osmoregulated periplasmic glucans (OPGs) in bacteria. These OPGs are present in all known proteobacteria and are formed by 5-24 D-glucose molecules bound by means of $\beta$-glycosidic bonds. The concentration of these glucans has been reported to change with variations in periplasmic osmolarity [36]. Due to their big size, OPGs are trapped in the periplasm, being unable to diffuse to the outside of cells. In E. coli, the carbon skeleton is synthesized by proteins coded by genes opgG (mdog orthologous) and $o p g H$. OpgH is a glucosyl transferase that synthesizes the lineal skeleton of glucose units by means of $\beta-1,2$ bonds. In E. coli, MdoG is a $56 \mathrm{kDa}$ periplasmic protein necessary for the polymerization of sugar molecules, although its function has not being completely established [36]. In A. ferrooxidans, putative MdoG ( $57.4 \mathrm{kDa}$ ) has been previously identified as a component of its periplasm [37]. In E. coli both opgG and opgH genes form part of the same operon. By analyzing the genomic context of $A$. ferrooxidans instead, it was found that $m d o G$ and $m d o H$ are separated by an open reading frame (ORF) coding for a protein of unknown function. On the other hand, protein $\mathrm{MdoH}$ did not change its levels in the results obtained here. The system for OPGs synthesis in E. coli involves four additional proteins (OpgD, OpgB, OpgC and OpgE) whose equivalent genes are absent in A. ferrooxidans genome. Nevertheless, only OpgG and OpgH are strictly necessary for the OPGs synthesis in E. coli [38]. OPGs biosynthesis starts with glucose transport to form glucose-6P, which is used to generate (uridine diphosphate glucose) UDP-glucose for production of OPGs via OpgH/OpgG [36]. It is known this molecule is formed by a glucose 1-phosphate uridil transferase that catalyzes the UTP and a proton addition to D-glucose-1-phosphate to generate UDP-D-glucose [39]. It can be suggested that generation of OPGs in A. ferrooxidans would involve also a higher UDP-glucose synthesis. Since this process consumes protons, it should alleviate excessive entrance of these cations when RND efflux pumps are heavily used to remove copper.

The CusA proton/ $\mathrm{Cu}$ antiporter system is overexpressed in A. ferrooxidans subjected to copper as already seen in Figure 1, and under those conditions, a higher number of protons would be expected to enter the cytoplasm from the growth medium, as already suggested by the results shown in Figure 2 . Thus, a higher synthesis of OPGs would also consume protons, in favor of keeping the normal cytoplasmic $\mathrm{pH}$. Furthermore, it has been shown that an OPGs preparation acts as a blocker and a regulator of an OMPC-like porin channel selective of cations in E. coli [40]. On the other hand, cells unable to form OPGs showed an increased synthesis of OmpC [41]. It has also been documented that porins mediate copper entrance in Mycobacterium tuberculosis [42]. The existence of a relationship 
between both copper entrance and porins closing or decreasing their levels of synthesis is possible then, as seen here for OprB in A. ferrooxidans ATCC 53993 (Table 1). Examples of this behavior were previously reported for the major A. ferrooxidans porin Omp40 (Afe_2741) and OmpA (Afe_2685) in A. ferrooxidans ATCC 23270 [21].

To support proteomic results, transcriptional levels of genes coding for proteins MdoG and porins, were also determined in cells grown at different copper concentrations as shown in Figure 3. The results clearly indicate increasing levels of synthesis of mRNA coding for MdoG and decreasing levels of messenger RNAs for porin genes omp40, oprB and ompA, confirming the proteomic results already discussed. It is, therefore, possible that lower levels of porins, together with higher OPGs amounts, constitute a defense response to extreme copper conditions as seen here in A. ferrooxidans ATCC 53993, an idea that should be proven.

A

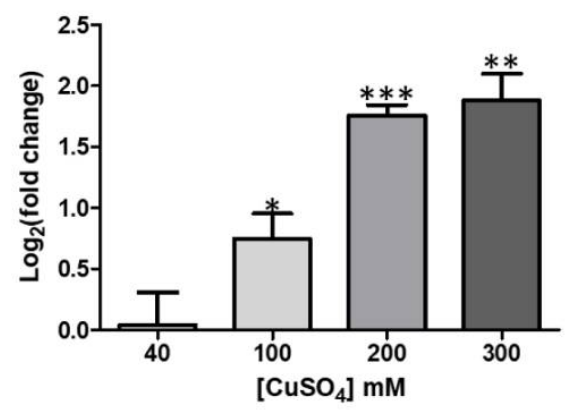

C

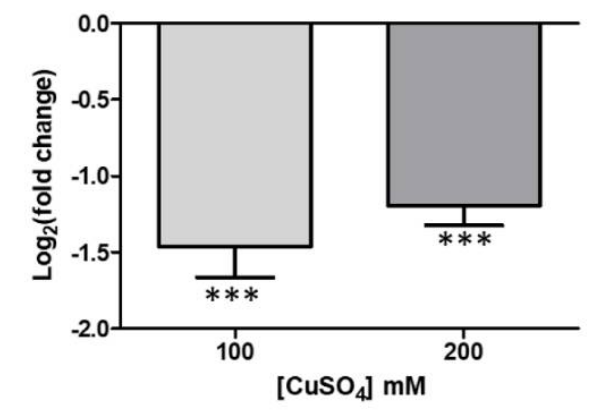

B

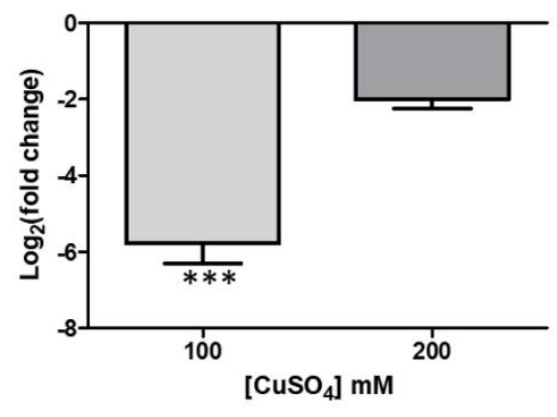

D

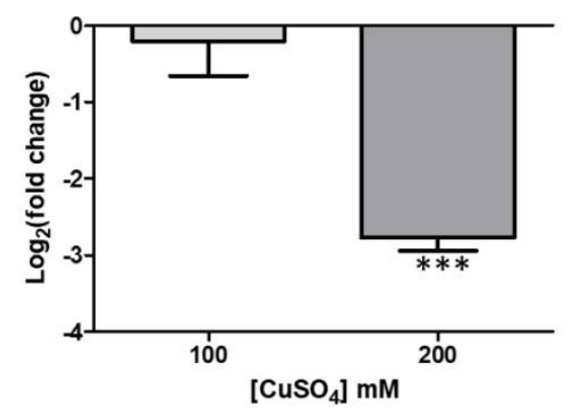

Figure 3. Transcriptional levels of selected envelope genes. (A) $m d o G$; (B) oprB, (C) ompA and (D) omp40 in A. ferrooxidans ATCC 53993 grown in different copper concentrations. Error bars indicate standard deviations based on three different experimental values. Application of $t$-Student test were: *** $p \leq 0.001{ }^{* *} p \leq 0.01$ and $* p \leq 0.05$.

Currently there are no efficient and easy to reproduce methods to generate knock-outs of genes in A. ferrooxidans [43]. Therefore, to ascertain whether the $m d o G$ gene confers Cu-resistance to a heterologous host, it was expressed in E. coli as described in Materials and Methods. As seen in Figure 4, A. ferrooxidans putative $m d o G$ gene conferred resistance to $\mathrm{Cu}$ when expressed in $E$. coli due to the increase of its MIC value from 1.0 to $3.0 \mathrm{mM}$ copper. This result supports the possibility of MdoG being a copper resistance determinant in this acidophilic microorganism. In addition, the effect of overexpressing $m d o G$ in $E$. coli was also tested in cells grown in the presence of $\mathrm{Zn}$ or $\mathrm{Ni}$ as shown in Figure 4. 


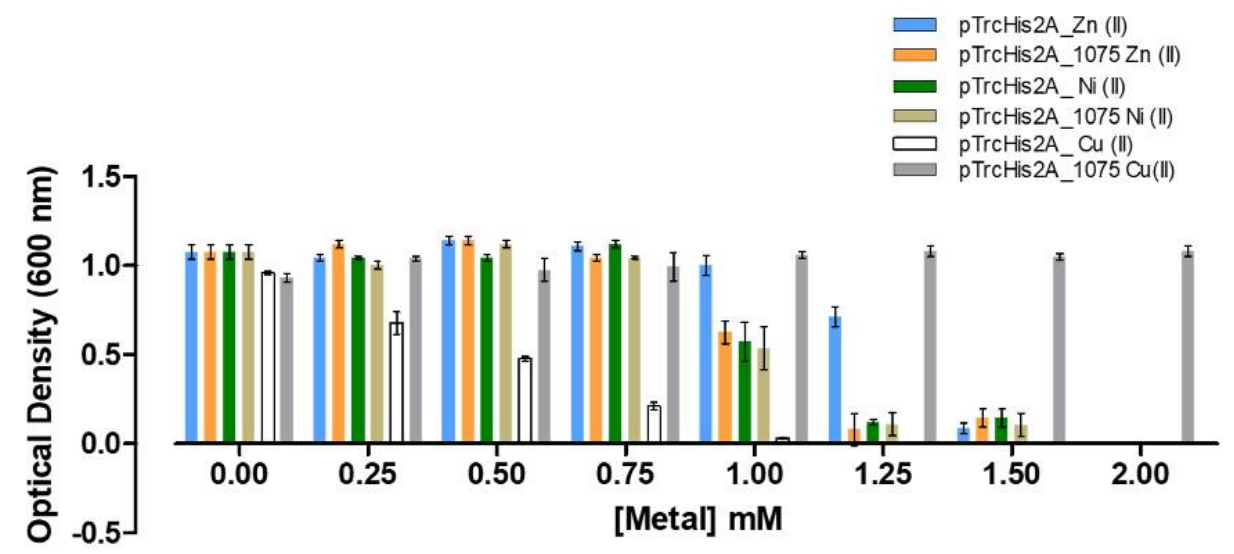

Figure 4. Heterologous functional analysis of the overexpression of A. ferrooxidans mdoG (Lferr_1075) gene in the Cu-sensitive Escherichia coli (K-12 $\triangle \operatorname{cop} A / \triangle c u s C F B A / \triangle c u e O)$ grown in zinc (Zn), nickel (Ni) and copper $(\mathrm{Cu})$. pTrcHis2A, empty vector; pTrcHis2A_1075 contains mdoG gene. Error bars indicate standard deviations based on three different experimental values.

Compared with copper, MdoG did not confer tolerance to Ni and Zn. Interestingly, a proteomic analysis of the response of Rhodobacter sphaeroides to high cobalt concentrations has been reported [44]. One of the changing proteins in presence of the metal was MdoG. It was previously suggested that cobalt would generate an alteration of permeability of the envelope, periplasm or cell wall as a possible resistance mechanism in this microorganism [44]. Whether the effect of copper is rather specific for MdoG from A. ferrooxidans remains to be elucidated. Another interesting protein found to be overexpressed in presence of copper was Lferr_0408 (Wzy) (Table 1), a protein involved in O-antigen biosynthesis, the most external segment of LPS [45,46]. By expressing gene wzy from A. ferrooxidans in the $\mathrm{Cu}$-sensitive $E$. coli $(\mathrm{K}-12 \Delta c o p A / \triangle c u s C F B A / \triangle c u e O)$ strain already used for $m d o G$ gene, the results seen in Figure 5 were obtained. Once again, it is clear that expressing $w z y$ gene in the heterologous host confers it a higher copper resistance.

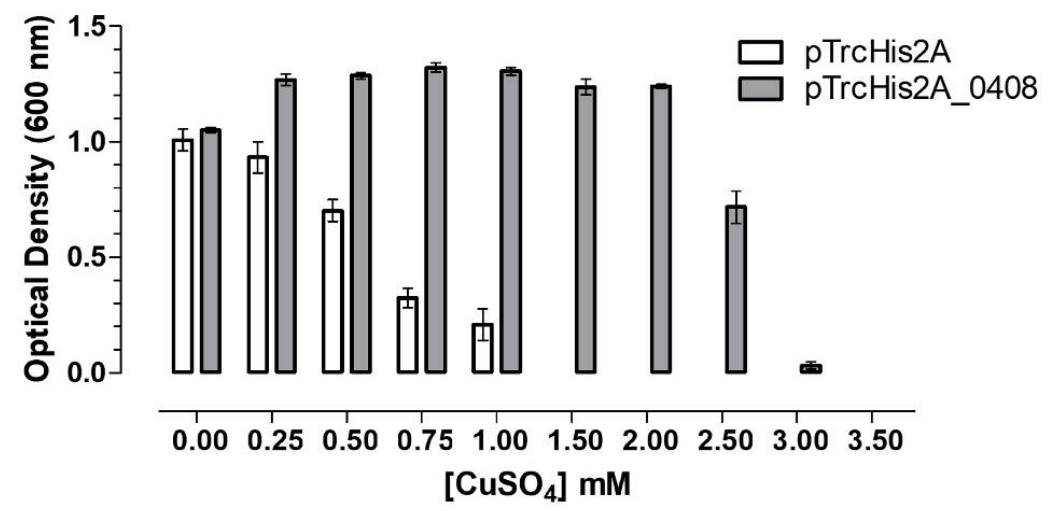

Figure 5. Heterologous functional analysis of overexpression of $A$. ferrooxidans antigen-O polymerase

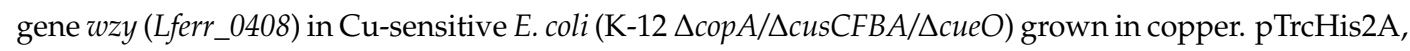
empty vector; pTrcHis2A_0408 contains gene $w z y$. Error bars indicate standard deviations based on three different experimental values.

To support this result, the analysis of transcriptional expression of this and other genes involved in LPS generation was carried out. Figure 6 shows the levels of transcriptional expression of $w z y$, $w z z$ and $r f a E$ genes, all involved with LPS synthesis, in both A. ferrooxidans strains grown in the absence or presence of copper. 
A

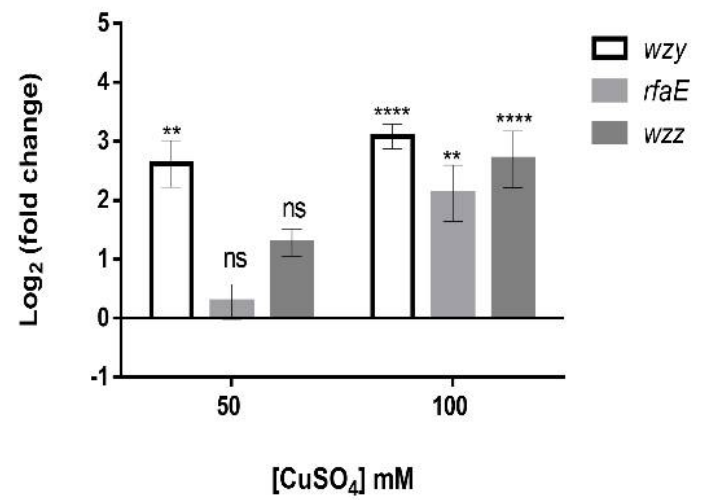

B

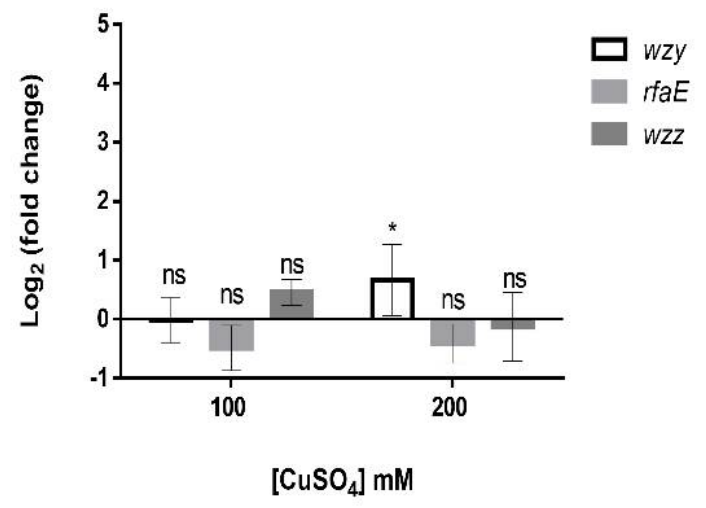

Figure 6. Transcriptional levels of genes $w z y$, $w z z$ and $r f a E$ related to lipopolysaccharides (LPS) synthesis in A. ferrooxidans exposed to copper. (A) Strain ATCC 23270; (B) Strain ATCC 53993. Values were obtained from three biological replicates. Error bars indicate standard deviations based on three different experimental values. Application of $t$-Student test were: ${ }^{* * * *} p \leq 0.0001^{* *} p \leq 0.01$ and ${ }^{*} p \leq 0.05$.

Strain ATCC 23270 clearly showed an increased level in expression of tested genes in presence of the metal (Figure 6A). On the contrary, the same genes did not show significant changes in their expression when strain ATCC 53993 was grown in presence of copper (Figure 6B). These results strongly suggest strain ATCC 23270 could synthesize higher amounts of LPS in presence of copper compared to ATCC 53993. However, when the amounts of LPS were determined in both strains in absence of the metal, ATCC 53993 showed about 3-fold higher amounts of LPS compared with ATCC 23270 (Figure 7A). This result indicates that normally, strain ATCC 53993 in addition of having extra copper resistance determinants in its genomic island, contains higher LPS levels compared with strain ATCC 23270. This could explain in part the higher copper tolerance of the former strain.

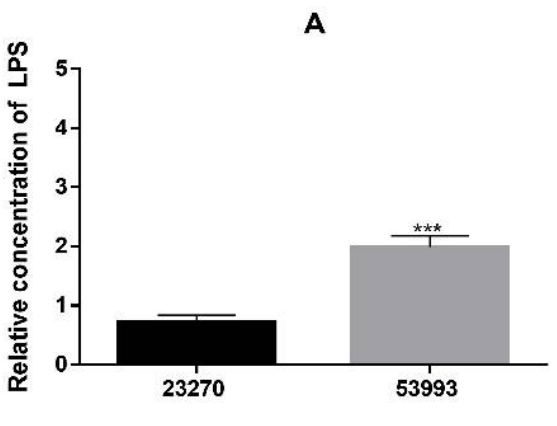

Strain

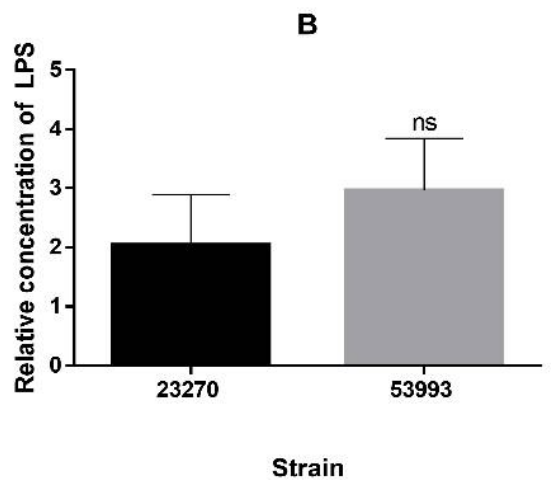

Strain

Figure 7. Relative LPS concentration of A. ferrooxidans ATCC 23270 and ATCC 53993 grown at different concentrations of $\mathrm{CuSO}_{4}$. (A) Cells grown in absence of copper; (B) Cells grown in $100 \mathrm{mM} \mathrm{CuSO}_{4}$. Values were obtained from three biological replicates. Error bars represent standard deviations for each condition. A $t$-Student statistic analysis was performed, where: ${ }^{* * *}$ indicates $p \leq 0.001$ and ns indicates $p>0.05$.

Nonetheless, in presence of $100 \mathrm{mM}$ copper both strains showed similar LPS levels (Figure 7B), suggesting that strain 23270 increases its LPS levels in presence of the metal, in agreement with results of the transcriptional expression of its genes in the presence of copper seen in Figure 6. Previously, A. ferrooxidans ATCC 53993 subjected to $40 \mathrm{mM} \mathrm{Cu}$ showed an increased level of protein RfaE possibly involved in LPS synthesis [22]. Apparently, LPS could bind metals in the cell surface depending on the 
composition of the polymers [47]. A summary of the main results obtained is shown in the working model of Figure 8.

Remarkably, it has been reported that $A$. ferrooxidans adapted to high copper and zinc ions concentrations showed changes in the surface chemical properties of this bacterium. Under these conditions, their surface negative charge was decreased due to changes in the structure of its surface layers [48].

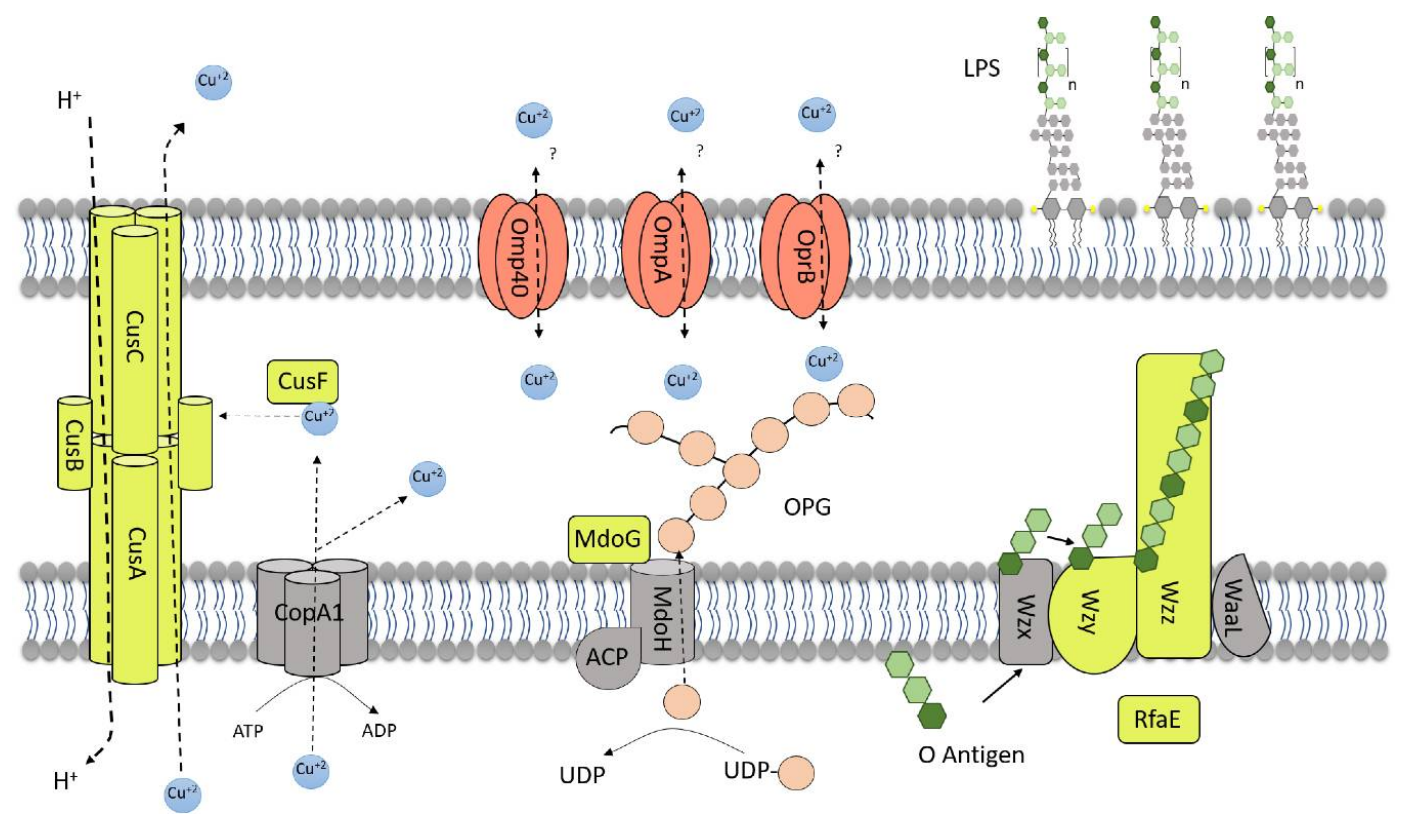

Figure 8. Summary working model of some proteins in A. ferrooxidans adapted to grow in presence of copper mentioned in this study. Yellow, proteins that increase their synthesis or transcript levels in presence of copper. Pink, proteins down-regulated in cells subjected to copper. OPG stands for osmoregulated periplasmic glucans. The locations and order in which proteins are illustrated are arbitrary.

\section{Conclusions}

The results presented here clearly indicate that several envelope components from A. ferrooxidans such as RND efflux pumps, LPS, porins, and periplasmic protein MdoG may be of great relevance for both, copper resistance and/or tolerance in their environment. Similar roles for these components in other members of the biomining bacterial consortia are also possible and their study may be of importance for industrial bioleaching operations.

Supplementary Materials: The following are available online at http:/ /www.mdpi.com/2073-4425/9/7/347/s1. Figure S1: Functional categories of $A$. ferrooxidans proteins changing their synthesis levels in cells grown in presence of 100 and $200 \mathrm{mM} \mathrm{CuSO}_{4}$. Table S1: Functional categories and numbers of A. ferrooxidans ATCC 53993 proteins changing their synthesis levels in cells grown in presence of 100 and $200 \mathrm{mM} \mathrm{CuSO}_{4}$. Table S2: Proteins with increased levels in A. ferrooxidans ATCC 53993 grown in presence of 100 and $200 \mathrm{mM} \mathrm{CuSO}_{4}$. Table S3: Proteins with lower levels of synthesis in A. ferrooxidans ATCC 53993 grown in presence of 100 and $200 \mathrm{mM} \mathrm{CuSO}_{4}$.

Author Contributions: N.O., C.A.N., S.A.Á., A.P., and C.A.J. conceived and designed the experiments. N.O., R.N., F.A., and C.M.-B. performed the experiments. N.O., R.N., A.P. and C.A.J. wrote the paper. All authors revised the manuscript.

Funding: This research was funded by FONDECYT grant number 1150791 to Carlos A. Jerez.

Acknowledgments: This work was part of the Ph.D. thesis of Nia Oetiker supported by CONICYT-PCHA/Doctorado Nacional/2013- 21130264.

Conflicts of Interest: The authors declare no conflict of interest. 


\section{References}

1. Vera, M.; Schippers, A.; Sand, W. Progress in bioleaching: Fundamentals and mechanisms of bacterial metal sulfide oxidation-Part A. Appl. Microbiol. Biotechnol. 2013, 97, 7529-7541. [CrossRef] [PubMed]

2. Rawlings, D.E. Characteristics and adaptability of iron- and sulfur-oxidizing microorganisms used for the recovery of metals from minerals and their concentrates. Microb. Cell Fact. 2005, 4, 1-15. [CrossRef] [PubMed]

3. Valenzuela, L.; Chi, A.; Beard, S.; Orell, A.; Guiliani, N.; Shabanowitz, J.; Hunt, D.F.; Jerez, C.A. Genomics, metagenomics and proteomics in biomining microorganisms. Biotechnol. Adv. 2006, 24, 197-211. [CrossRef] [PubMed]

4. Jerez, C.A. The use of genomics, proteomics and other OMICS technologies for the global understanding of biomining microorganisms. Hydrometallurgy 2008, 94, 162-169. [CrossRef]

5. Jerez, C.A. Bioleaching and biomining for the industrial recovery of metals. Compr. Biotechnol. 2011, 3, 717-729.

6. Navarro, C.A.; von Bernath, D.; Jerez, C.A. Heavy metal resistance strategies of acidophilic bacteria and their acquisition: Importance for biomining and bioremediation. Biol. Res. 2013, 46, 363-371. [CrossRef] [PubMed]

7. Watling, H.R. The bioleaching of sulphide minerals with emphasis on copper sulphides-A review. Hydrometallurgy 2006, 84, 81-108. [CrossRef]

8. Watkin, E.L.J.; Keeling, S.E.; Perrot, F.A.; Shiers, D.W.; Palmer, M.L.; Watling, H.R. Metals tolerance in moderately thermophilic isolates from a spent copper sulfide heap, closely related to Acidithiobacillus caldus, Acidimicrobium ferrooxidans and Sulfobacillus thermosulfidooxidans. J. Ind. Microbiol. Biotechnol. 2009, 36, 461-465. [CrossRef] [PubMed]

9. Jerez, C.A. Biomining of metals: How to access and exploit natural resource sustainably. Microb. Biotechnol. 2017, 10, 1191-1193. [CrossRef] [PubMed]

10. Franke, S.; Grass, G.; Rensing, C.; Nies, D.H. Molecular analysis of the copper-transporting efflux system CusCFBA of Escherichia coli. J. Bacteriol. 2003, 185, 3804-3812. [CrossRef] [PubMed]

11. Padilla-Benavides, T.; Thompson, A.M.G.; McEvoy, M.M.; Argüello, J.M. Mechanism of ATPase-mediated $\mathrm{Cu}^{+}$export and delivery to periplasmic chaperones: The interaction of Escherichia coli CopA and CusF. J. Biol. Chem. 2014, 289, 20492-20501. [CrossRef] [PubMed]

12. Argüello, J.M.; Raimunda, D.; Padilla-Benavides, T. Mechanisms of copper homeostasis in bacteria. Front. Cell. Infect. Microbiol. 2013, 3, 1-14. [CrossRef] [PubMed]

13. Cárdenas, J.P.; Quatrini, R.; Holmes, D.S. Genomic and metagenomic challenges and opportunities for bioleaching: A mini-review. Res. Microbiol. 2016, 167, 529-538. [CrossRef] [PubMed]

14. Orellana, L.H.; Jerez, C.A. A genomic island provides Acidithiobacillus ferrooxidans ATCC 53993 additional copper resistance: A possible competitive advantage. Appl. Microbiol. Biotechnol. 2011, 92, 761-767. [CrossRef] [PubMed]

15. Remonsellez, F.; Orell, A.; Jerez, C.A. Copper tolerance of the thermoacidophilic archaeon Sulfolobus metallicus: Possible role of polyphosphate metabolism. Microbiology 2006, 152, 59-66. [CrossRef] [PubMed]

16. Dopson, M.; Holmes, D.S. Metal resistance in acidophilic microorganisms and its significance for biotechnologies. Appl. Microbiol. Biotechnol. 2014, 98, 8133-8144. [CrossRef] [PubMed]

17. Orell, A.; Navarro, C.A.; Arancibia, R.; Mobarec, J.C.; Jerez, C.A. Life in blue: Copper resistance mechanisms of bacteria and Archaea used in industrial biomining of minerals. Biotechnol. Adv. 2010, 28, 839-848. [CrossRef] [PubMed]

18. Orell, A.; Navarro, C.A.; Rivero, M.; Aguilar, J.S.; Jerez, C.A. Inorganic polyphosphates in extremophiles and their possible functions. Extremophiles 2012, 16, 573-583. [CrossRef] [PubMed]

19. Martínez-Bussenius, C.; Navarro, C.A.; Jerez, C.A. Microbial copper resistance: Importance in biohydromrtallurgy. Microb. Biotechnol. 2017, 10, 279-295. [CrossRef] [PubMed]

20. Dopson, M.; Ossandon, F.J.; Lövgren, L.; Holmes, D. Metal resistance or tolerance? Acidophiles confront high metal loads via both abiotic and biotic mechanisms. Front. Microbiol. 2014, 5, 1-4. [CrossRef] [PubMed]

21. Almárcegui, R.J.; Navarro, C.A.; Paradela, A.; Albar, J.P.; von Bernath, D.; Jerez, C.A. New copper resistance determinants in the extremophile Acidithiobacillus ferrooxidans: A quantitative proteomic analysis. J. Proteome Res. 2014, 7, 946-960. [CrossRef] [PubMed] 
22. Martínez-Bussenius, C.; Navarro, C.A.; Orellana, L.; Paradela, A.; Jerez, C.A. Global response of Acidithiobacillus ferrooxidans ATCC 53993 to high concentrations of copper: A quantitative proteomics approach. J. Proteom. 2016, 145, 37-45. [CrossRef] [PubMed]

23. Amaro, A.M.; Chamorro, D.; Seeger, M.; Arredondo, R. Effect of external $\mathrm{pH}$ perturbations on in vivo protein synthesis by the acidophilic bacterium Thiobacillus ferrooxidans. J. Bacteriol. 1991, 173, 910-915. [CrossRef] [PubMed]

24. Ramos-Fernández, A.; Paradela, A.; Navajas, R.; Albar, J.P. Generalized method for probability-based peptide and protein identification from tandem mass spectrometry data and sequencue database searching. Mol. Cell. Proteom. 2008, 7, 1748-1754. [CrossRef] [PubMed]

25. López-Serra, P.; Marcilla, M.; Villanueva, A.; Ramos-Fernández, A.; Palau, A.; Leal, L.; Wahi, J.E.; Setien-Baranda, F.; Szczesna, K.; Moutinho, C.; et al. A DERL3-associated defect in the degradation of SLC2A1 mediates the Warburg effect. Nat. Commun. 2014, 5, 3608. [CrossRef] [PubMed]

26. Vera, M.; Pagliai, F.; Guiliani, N.; Jerez, C.A. The chemolithoautotroph Acidithiobacillus ferrooxidans can survive under phosphate-limiting conditions by expressing a C-P lyase operon that allows it to grow on phosphonates. Appl. Environ. Microbiol. 2008, 74, 1829-1835. [CrossRef] [PubMed]

27. Alvarez, S.; Jerez, C.A. Copper ions stimulate polyphosphate degradation and phosphate efflux in Acidithiobacillus ferrooxidans. Appl. Environ. Microbiol. 2004, 70, 5177-5182. [CrossRef] [PubMed]

28. Navarro, C.A.; Orellana, L.H.; Mauriaca, C.; Jerez, C.A.; Navarro, C.A.; Orellana, L.H.; Mauriaca, C.; Jerez, C.A. Transcriptional and functional studies of Acidithiobacillus ferrooxidans genes related to survival in the presence of copper. Appl. Environ. Microbiol. 2009, 75, 6102-6109. [CrossRef] [PubMed]

29. Rozen, S.; Skaletsky, H. Primer3 on the WWW for general users and for biologist programmers. Methods Mol. Biol. 2000, 132, 365-386. [PubMed]

30. Pfaffl, M.W. A new mathematical model for relative quantification in real-time RT-PCR. Nucleic Acids Res. 2001, 29, e45. [CrossRef] [PubMed]

31. Hitchcock, P.J.; Brown, T.M. Morphological heterogeneity among Salmonella lipopolysaccharide chemotypes in silver-stained polyacrylamide gels. J. Bacteriol. 1983, 154, 269-277. [PubMed]

32. Quesenberry, M.S.; Lee, Y.C. A rapid formaldehyde assay using purpald reagent: Application under periodation conditions. Anal. Biochem. 1996, 234, 50-55. [CrossRef] [PubMed]

33. Lee, C.H.; Tsai, C.M. Quantification of bacterial lipopolysaccharides by the purpald assay: Measuring formaldehyde generated from 2-keto-3-deoxyoctonate and heptose at the inner core by periodate oxidation. Anal. Biochem. 1999, 267, 161-168. [CrossRef] [PubMed]

34. Baker-Austin, C.; Dopson, M. Life in acid: pH homeostasis in acidophiles. Trends Microbiol. 2007, 15, $165-171$. [CrossRef] [PubMed]

35. Quatrini, R.; Appia-Ayme, C.; Denis, Y.; Jedlicki, E.; Holmes, D.S.; Bonnefoy, V. Extending the models for iron and sulfur oxidation in the extreme acidophile Acidithiobacillus ferrooxidans. BMC Genom. 2009, 10, 394. [CrossRef] [PubMed]

36. Bohin, J.P. Osmoregulated periplasmic glucans in Proteobacteria. FEMS Microbiol. Lett. 2000, 186, 11-19. [CrossRef] [PubMed]

37. Chi, A.; Valenzuela, L.; Beard, S.; Mackey, A.J.; Shabanowitz, J.; Hunt, D.F.; Jerez, C.A. Periplasmic proteins of the extremophile Acidithiobacillus ferrooxidans. Mol. Cell. Proteom. 2007, 6, 2239-2251. [CrossRef] [PubMed]

38. Bontemps-Gallo, S.; Bohin, J.P.; Lacroix, J.M. Osmoregulated periplasmic glucans. EcoSal Plus $2017,7$. [CrossRef] [PubMed]

39. Weissborn, A.C.; Liu, Q.; Rumley, M.K.; Kennedy, E.P. UTP-D-glucose-1-phosphate uridylyltransferase of Escherichia coli: Isolation and DNA sequence of the galU gene and purification of the enzyme. J. Bacteriol. 1994, 176, 2611-2618. [CrossRef] [PubMed]

40. Delcour, A.H.; Adler, J.; Kung, C.; Martinac, B. Membrane-derived oligosaccharides (MDO's) promote closing of an E. coli porin channel. FEBS Lett. 1992, 304, 216-220. [CrossRef]

41. Fiedler, W.; Rotering, H. Properties of Escherichia coli mutants lacking membrane-derived oligosaccharides. J. Biol. Chem. 1988, 263, 14684-14689. [PubMed]

42. Speer, A.; Rowland, J.L.; Haeili, M.; Niederweis, M. Porins increase copper susceptibility of Mycobacterium tuberculosis. J. Bacteriol. 2013, 195, 5133-5140. [CrossRef] [PubMed] 
43. Gumulya, Y.; Boxall, N.J.; Khaleque, H.N.; Santala, V.; Carlson, R.P.; Kaksonen, A.H. In a quest for engineering acidophiles for biomining applications: Challenges and opportunities. Genes 2018, 9, 116. [CrossRef] [PubMed]

44. Pisani, F.; Italiano, F.; De Leo, F.; Gallerani, R.; Rinalducci, S.; Zolla, L.; Agostiano, A.; Ceci, L.R.; Trotta, M. Soluble proteome investigation of cobalt effect on the carotenoidless mutant of Rhodobacter sphaeroides. J. Appl. Microbiol. 2009, 106, 338-349. [CrossRef] [PubMed]

45. Lerouge, I.; Vanderleyden, J. O-antigen structural variation: Mechanisms and possible roles in animal/plant-microbe interactions. FEMS Microbiol. Rev. 2001, 26, 17-47. [CrossRef]

46. Snyder, D.S.; Brahamsha, B.; Azadi, P.; Palenik, B.; Acteriol, J.B. Structure of compositionally simple lipopolysaccharide from marine Synechococcus. J. Bacteriol. 2009, 191, 5499-5509. [CrossRef] [PubMed]

47. Langley, T.; Beveridge, T.J. Effect of O-side-chain-lipopolysaccharide chemistry on metal binding. Appl. Environ. Microbiol. 1999, 65, 489-498. [PubMed]

48. Vilinska, A.; Rao, K.H. Surface characterization of Acidithiobacillus ferrooxidans adapted to high copper and zinc ions concentration. Geomicrobiol. J. 2011, 28, 221-228. [CrossRef]

(c) 2018 by the authors. Licensee MDPI, Basel, Switzerland. This article is an open access article distributed under the terms and conditions of the Creative Commons Attribution (CC BY) license (http://creativecommons.org/licenses/by/4.0/). 